DOI 10.18551/rjoas.2020-03.19

\title{
OPTIMUM PROPORTION OF INDIAN SCAD (DECAPTERUS RUSSELLI) PROTEIN CONCENTRATE IN TRADITIONAL FOOD CAKE DESIGNATED FOR UNDERNOURISHED CHILDREN DIET
}

\author{
Kurniawan Antonius ${ }^{\star}$, Permadi Aef \\ Department of Fisheries Counseling, Fisheries Polytechnic of Jakarta, Indonesia \\ Purnomo Agus Heri \\ Research and Development Center for Marine and Fisheries Product Processing and \\ Biotechnology, Jakarta, Indonesia \\ *E-mail: antoniuskurniawan80@gmail.com
}

\begin{abstract}
The addition of fish protein concentrate (FPC) is expected to minimize protein malnutrition problem of children aged 3-6 years. This research was aimed to find the optimum proportion of FPC in the formulation of a type of traditional food cake that is popular among children in an area with a significant case malnutrition problem. The traditional food cake is 'gapit', an Indonesian flour based roasted cake while the area is Blora Regency of Central Java Province. The research was done in following an experimental methodological approach involving three treatments, namely HPI proportion, additional of flavoring agent, and roasting time. Determination of the optimum formula was done following the Response Surface Methodology (RSM) and was processed using the Design Expert (DX) Program Version 11. Using sensory parameters applied trough hedonic tests; the determination of optimum formula was carried out involving 90 untrained panelists of children aged 3-6 years from the 3 regions most affected by stunting in Blora Regency. The results showed that the optimum formula was that of $15 \%$ FPC with durian flavor and 2 minute roasting time. In terms of acceptance, this product is highly appreciated by panelists, indicated by odor, taste, color, and texture scores of $82 / 100,83 / 100,80 / 100$, and $84 / 100$, respectively; and desirability of $80 \%$. Nutrition-wise, the product has the composition of $4.8 \%$ moisture, $1.2 \%$ ash, $12.4 \%$ protein, $3 \%$ fat, and $81 \%$ carbohydrate.
\end{abstract}

\section{KEY WORDS}

Fish protein concentrate; gapit cake, optimization; response surface methodology

Protein deficiency is among disturbing malnutrition cases in Indonesia. Unless this case is taken care of seriously, the country will face multidimensional negative impacts. As reported, lack of protein will reduce the quality of life individuals with effects a decrease in the immune system (Maggini et al., 2018), causes of kwashiorkor and marasmus in children (Grover \& Ee, 2009; Kemenkes, 2013). Among segments of ages in a human life span, the children's phase is the most critical and important phase; physical, mental, as well as psychosocial development in the adult time are determined by how protein sufficiency is met in the childhood ages (UNHCR, 2001; Sulistiyowati, 2010).

Nationally, in Indonesia fish is available in abundance and affordable price (Ningsih, 2018; USAID, 2018). However, many fish production centers are located far away from the concentration of consumers (Ae et al., 2013). As the result, many locations remain lacking of access to cheap and enough amount fish and the people become susceptible to protein deficiency. Several species of fish are available in large quantities and relatively much cheaper compared to others, for example indian scad (Decapterus russelli) (Nugroho et al., 2013). The current national production of indian scad is 195.96 Tons/year (BPS, 2018) with average price of Rp 20,000.00/kg (BPS, 2017). Unfortunately, given the geographical size of the country to bring this source of protein from production centers to consumers is obviously a very challenging problem, both technically and economically. 
Fish Protein Concentrate (FPC) opens an opportunity to tackle the problem. FPC is a high protein product resulting from a process where water and oil is removed from fish, an excellent source of highly digestible amino acids and other nutrient materials (Mohamed et al., 2014). Among others, a way to remove oil and water from the fish the B type process, which includes cooking, pressing, and drying (Windsor, 2001; Widyaningsih et al., 1986). With FPC, the best part of the fish is made less voluminous and therefore can be transported more easily. Only parts with good functional characteristics are delivered to consumers.

The next challenge is because FPC is tasteless and not ready for consumption. One way overcome this challenge is by adding FPC to food making process such that the result will be a product of high protein content, acceptable taste and more added value (Allen \& Benois, 2006). A number of research regarding fortification FPC on food products can be found in literature. Among these research are FPC fortification on melarat crackers (Asriani, 2018), biscuits (Patimah et al., 2019; Afriani et al., 2016; Kholilah, 2002; Anugrahati, N.A et al., Anugrahati et al., 2012; Dewita et al., 2011), and on sweet bread (Defira et al., 2019 (Defira et al., 2019).

In line with the problem of protein deficiency mentioned earlier, the food to be fortified of course has to match with the preference of targeted consumers. For the case of children in the region of Blora Regency, there is a type of snack food that seems to be acceptable by children in the region. The snack food is called gapit. Gapit is a traditional cake very popular in Blora and in many other places in Indonesia. This cake is made from the basic ingredients of rice flour, sago flour, eggs, granulated sugar, and liquid coconut milk. It is called gapit because the process involves gapit, a local term for pinching (Khikmawati, 2014). Gapit is crispy and most importantly for child consumers it normally has sweet tastes. This then justifies an experimental research regarding the fortification of indian scad FPC on gapit snack food targeting school children aged 3-6 years.

\section{METHODS OF RESEARCH}

Steps of preparing the FPC can be seen in FIGURE 1 while steps for making gapit snack food are shown in FIGURE 2. Combinations of variables, namely the concentrations of the FPC and flour, and roasting time were tested to find the optimum ones according to organoleptic criteria. The organoleptic test was carried out using 30 untrained panelists of kindergarten schoolchildren aged 3-6 years drawn randomly from 3 regions of the most significant malnutrition case in the study location, Blora (BRHO, 2018). Three replications was adopted so that in total there were 90 data.

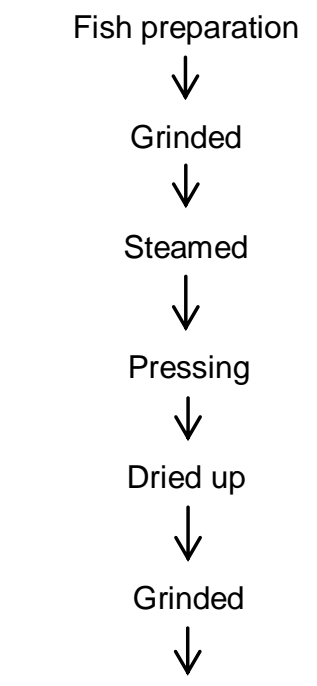

Fish Protein Concentrate

Figure 1 - Steps for FPC preparation 
Addition of FPC to gapit ingredients

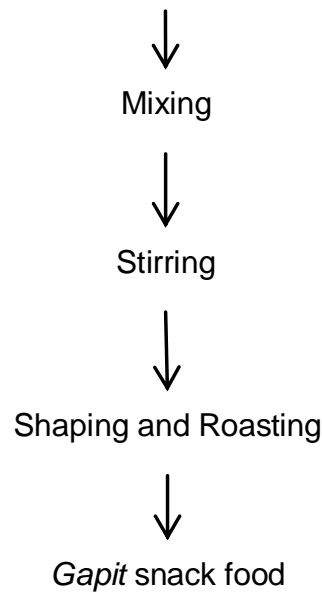

Figure 2 - Steps for gapit preparation

The next step of the research was formula optimization following the Response Surface Methodology (RSM) method (Montgomery, 2013), which is a collection of mathematical and statistical techniques used for modeling and analysis of problems in a response that is influenced by several variables and its purpose to optimize the response. Following from Oramahi (2016) this method was adopted in this research to know the effect of the independent variable on response, got a model of the relationship between the independent variable and the response and got the process conditions that produced the best response. The advantages of this RSM method include that it does not require large amounts of trial data and does not require a long time. Operationally, the approach was done through data processing using the Design Expert (DX) Program Version 11 (Stat-Ease, 2018). This consisted of 4 stages, namely: (1) preparing the formulation and response design, 2) formulation, 3) response analysis, and 4) optimization.

Formulation and response design was carried out using the DX 11 Program to determine fixed variables and independent variables. Fixed variable is a variable whose value is made the same in each treatment because it is considered not to affect the response. Meanwhile, the independent variable is a variable that will affect the response generated. In this study the fixed variable was the number of main ingredients in making the gapit snack food, namely the amount of sticky rice flour, tapioca flour, salt, sugar, and coconut milk, while the independent variable was the addition of the concentration of durian flavored indian scad FPC and the roasting time. Determination of the independent variable based on results of similar previous research Kholilah, 2002; Afriani et al., 2016; Nova \& Kristiastuti, 2017; Khikmawati, 2014) to determine the minimum and maximum limits, as seen in Table 1.

Table 1 - The range of independent variable values

\begin{tabular}{llll}
\hline Component & independent Variable & Minimum & Maximum \\
\hline A & Concentration fly fish protein concentrate (\%) & 10 & 20 \\
B & Time (Minute) & 1 & 3 \\
\hline
\end{tabular}

Minimum and maximum limit values were entered into the DX11 RSM Box-Behnken Design program for randomization. After randomization of the combinations, 15 treatments to be analyzed were determined (Table 2). Responses to be measured and optimized responses were brought to an organoleptic test, which involved odor, taste, color, and texture criteria. And following the BSN (2006) standard, evaluation of the tested sample was done by giving quality assessment based on like or not like panelist's judgment to product. The results of this descriptive test of all panelists were then compiled. 
In this step, gapit snack food was made according to the formulas shown in Table 2 with a base ingredient composition as shown in Table 3 and a process flow diagram presented in FIGURE 3. As shown in this figure, the process started with weighing the base ingredients. Then, durian flavored indian scad FPC was added according to the formula produced by the program. This was based on a trial and error which referred to research results Kholilah (2002), Anugrahati et al. (2012). Next was mixing and stirring until tender dough was produced. The dough was then was shaped and roasted. The roasting time was based on a trial and error testing which referred to research results of Hapsoro (2013), Hasan et al. (2014), Nitisari (2016), and Khikmawati (2014).

Table 2 - Experimental design of gapit snack food processing

\begin{tabular}{lll}
\hline \multirow{2}{*}{ Formula } & Factor 1 & Factor 2 \\
& A: Concentration fish protein concentrate (\%) & Time (Minute) \\
\hline 1 & 15 & 2 \\
2 & 20 & 3 \\
3 & 7.93 & 2 \\
4 & 15 & 2 \\
5 & 15 & 2 \\
6 & 15 & 0.58 \\
7 & 15 & 2 \\
8 & 15 & 3.41 \\
9 & 20 & 1 \\
10 & 10 & 3 \\
11 & 15 & 2 \\
12 & 10 & 1 \\
13 & 22.1 & 2 \\
\hline
\end{tabular}

Table 3 - Initial formulation of making Gapit cake

\begin{tabular}{ll}
\hline Ingredients & Weight, $\mathrm{g}$ \\
\hline Glutinous rice flour & 1000 \\
Tapioca flour & 125 \\
Salt & 5 \\
Garlic & 10 \\
Sugar & 300 \\
Coconut milk & 150 \\
\hline
\end{tabular}

Each response variable was then analyzed using the Quadratic ANOVA. This ANOVA model was adopted as it was the one that gave significance to ANOVA and non-significance to lack of fit. In addition, this was also based on the result of the DX 11 Program, which provided a normal plot of residual, indicating whether the difference between the actual response and the predicted response value followed the normality line (straight line). Normal line data indicated that actual results would be close to the results predicted by the DX program (Nurmiah et al., 2013).

At this step, each response (odor, taste, color, texture) was determined by the objective of optimization stated in the Design Expert 11 Program. This program carried out optimization according to the inputted variable data and response measurement data. The output of the optimization stage was the recommendation of several new optimal formulas according to the program. The most optimal formula was a formula with a maximum desirability value. Desirability value was the value of the objective optimization function that showed the ability of the program to fulfill desires based on criteria set on the final product. The values ranged between 0 and 1.0. The desirability value which was close to 1.0 indicated better ability of the program to produce the desired product. The purpose of optimization was not to obtain a desirability value of 1.0 , but to find the best conditions that brought together all the objective functions (Nurmiah et al., 2013; Rushing et al., 2013).

The proximate analysis consisted of moisture content analysis using the oven evaporation method following the Indonesian National Standard (SNI) 01-2891-1992 (BSN, 1992), ash content analysis using dry ashing method following the SNI 01-2891-1992 (BSN, 1992), protein content analysis using the Kjeldahl method (BSN, 2011), fat content analysis 
using the Soxhlet method (SNI 01-2891-1992) (BSN, 1992), and carbohydrate content analysis using the by difference method (Nielsen, 2010).

\section{RESULTS AND DISCUSSION}

The effect of variation of formula and roasting time on acceptability of the product was detected. Table 4 shows the processed data of respondents' preference scoring on the smell, taste, color, and texture of the products of different composition and roasting time. The table shows that the ranges of scores were 65 to 87 for odor, 48 to 87 for taste, 60 to 87 for color, and texture 60 to 86 for texture.

Table 4 - Processed data of respondents' preference scoring

\begin{tabular}{lllllll}
\hline Formula & $\begin{array}{l}\text { FPC } \\
(\%)\end{array}$ & $\begin{array}{l}\text { TIME } \\
(\text { MINUTE) }\end{array}$ & ODOR & TASTE & COLOR & TEXTURE \\
\hline 1 & 15.00 & 2.00 & 82 & 83 & 80 & 86 \\
2 & 20.00 & 3.00 & 83 & 82 & 82 & 81 \\
3 & 7,93 & 2.00 & 82 & 84 & 86 & 86 \\
4 & 15.00 & 2.00 & 79 & 81 & 82 & 80 \\
5 & 15.00 & 2.00 & 78 & 84 & 70 & 84 \\
6 & 15.00 & 0.59 & 65 & 48 & 76 & 60 \\
7 & 15.00 & 2.00 & 80 & 77 & 82 & 82 \\
8 & 15.00 & 3.41 & 75 & 81 & 76 & 80 \\
9 & 20.00 & 1.00 & 78 & 62 & 60 & 86 \\
10 & 10.00 & 3.00 & 86 & 87 & 87 & 86 \\
11 & 15.00 & 2.00 & 87 & 84 & 83 & 84 \\
12 & 10.00 & 1.00 & 77 & 83 & 80 & 85 \\
13 & 22,07 & 2.00 & 77 & 80 & 80 & \\
\hline
\end{tabular}

Furthermore, the analysis of variance (ANOVA) performed to follow up these results produced numbers as presented in Table 5, which suggests that quadratic model was found better than other models. The quadratic model has a larger $\mathrm{R}^{2}$ value than the other models: 0.64 for odor, 0.86 for taste, 0.57 for color, and 0.88 for texture. Furthermore, using the $p<$ 0.05 criteria, the model also was found significant for most preference criteria $(0.044$ for odor, 0.0091 for taste, and 0.0018 ). This means that variation in the snack formula and roasting time statistically had a significant effect on panelists' preference on smell, taste, and texture, and not for the color of the product.

The Lack of Fit (LoF) test also showed that the model was found good. The $p$ value of the LoF test was 0.2385 for odor, 0.0504 for taste, 0.2988 for color, and 0.1384 for texture, all of which were greater than 0.05 . The results of the test indicated that the LoF was not significant. Referring to the literature (Keshani et al., 2010; Nurmiah et al., 2013; Sukasih et al., 2018), this means that the model is good model as it shows suitability of the response data with the model.

Table 5 - Result of analysis of variance

\begin{tabular}{|c|c|c|c|c|c|}
\hline Response & Model & Equation & $\begin{array}{l}\text { Significance } \\
(p<0.05)\end{array}$ & $\begin{array}{l}\text { Lack of Fit } \\
(p<0.05)\end{array}$ & $\mathrm{R}^{2}$ \\
\hline Odor & Quadratic & $Y=81.20-1.13 A+3.52 B+1.00 A B+0.71 A^{2}+4.04 B^{2}$ & 0.0440 & 0.2385 & 0.6426 \\
\hline Teste & Quadratic & $Y=81.80-3.96 A+8.83 B+4.00 A B+1.41 A^{2}-7.34 B^{2}$ & 0.0091 & 0.0504 & 0.8564 \\
\hline Color & Quadratic & $Y=79.4-4.19 A+3.62 B+3.75 A B+1.24 A^{2}-2.26 B^{2}$ & 0.3640 & 0.2988 & 0.5722 \\
\hline Texture & Quadratic & $Y=83.60-2.30 A+4.91 B+4.75 A B+0.95 A^{2}-6.80 B^{2}$ & 0.0018 & 0.1384 & 0.8761 \\
\hline
\end{tabular}

Note: $A=$ durian flavored $F P C, B=$ time.

Following from Winarno (2004) and Trihaditia et al. (2018) regarding sensory observation of odor, the following is the results of the RSM odor response equation performed to optimize the condition of the process of FPC fortification to gapit snack food:

$$
\text { Odor }=-1.13 A+3.52 B+A B+0.71 A^{2}+4.04 B^{2}
$$


Where: A - Proportion of FPC (\%); B - Time (min).

The equation showed that the odor response would increase directly proportional to the increase in time and inversely proportional to component of FPC. The lower roasting time and the higher concentration of FPC the lower the panelists' preference for the odor response to the gapit and this result is in line with the study of Nurmiah et al. (2013).

The validity of this result was confirmed by the data normality test as presented below. Figure 3 shows the normal plot of residual odor response, which indicates normality of data. As seen by this figure, there are strong relationship between the actual value and the predicted value. Referring to Trihaditia et al. (2018), this can be interpreted that the actual results would be close to the results predicted by the DX Program.

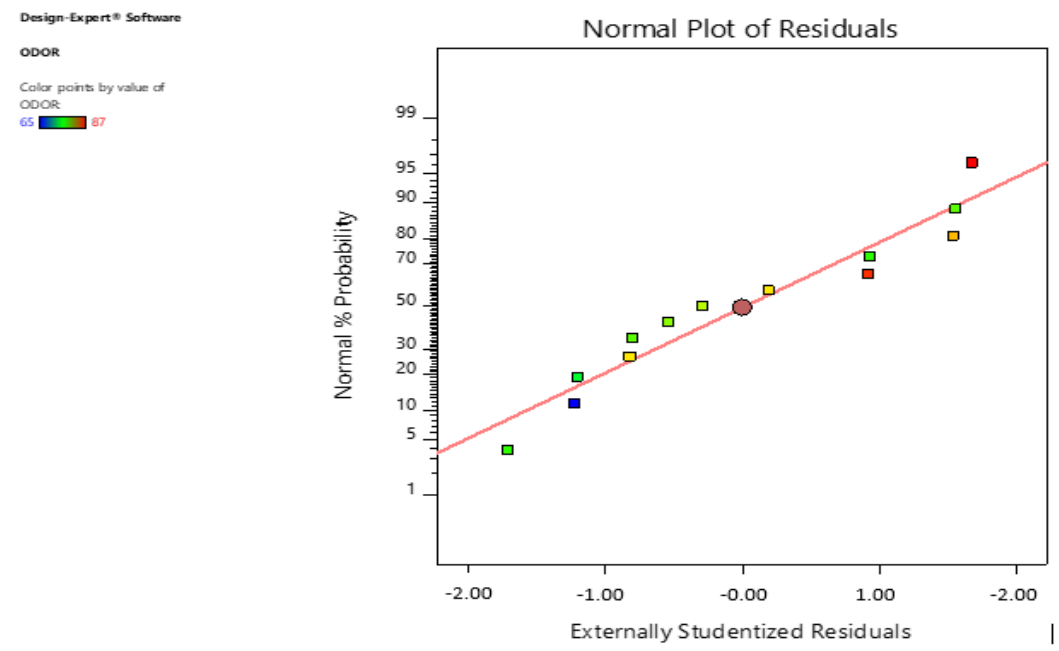

Figure 3 - Normal plot of residual odor response

Using the above equation formula, FIGURE 4 shows a contour plot graph which links the value odor response and combinations of treatments (FPC proportion and roasting time. More specifically, the graph provides the following: (i) different colors which reflect different values of odor response and (ii) dotted lines which show combinations of treatments that produce the same odor response value, (iii) the effect of the combination of treatments on odor response.
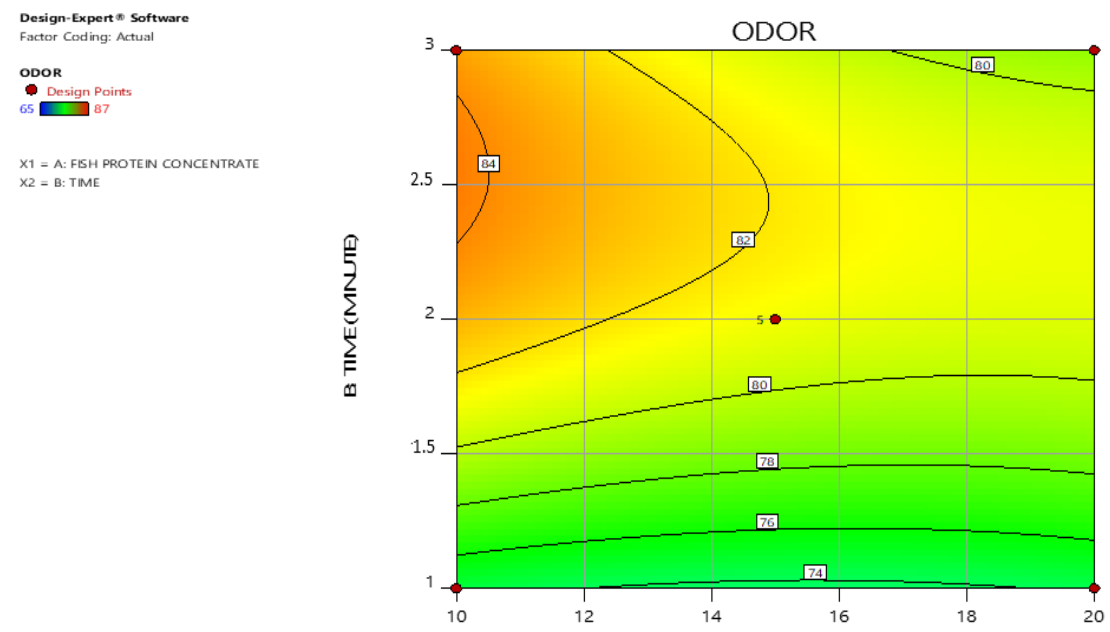

Figure 4 - Contour plot graph of odor response / optimization region of odor

As seen in the graph, the lowest odor response value is 65 , which is indicated by the blue color; meanwhile, the highest odor response is 87 , which is indicated by the red color. It was found that the higher the FPC and the shorter the roasting time, the smaller is the value 
of odor response. Referring to finding of Widyaningsih et al. (1986), this can be linked to the addition of Type B FPC and incomplete roasting process; in this case, the aroma and taste of fish still remains in the product added with the Type B FPC, and conversely the lower concentration of fish protein concentrate and the longer roasting time then the greater odor response. More explanation can be found in Irmayanti et al. (2017), who stated that such phenomenon occurred because during roasting, temperature increased and made volatile aroma-forming compounds evaporate.

As also seen in the graph, the boundary area for optimization has the lowest value of 74 and the highest value of 84 . In this case, the predicted odor optimum value is indicated by the red point, which is 81.2 . This value corresponds to a FPC proportion of $15 \%$ and roasting time of 2 (two) minutes roasting.

The notion of taste in this research refers to something that is felt by the taste buds of taste can help in the identification, naming, and appreciation of food. And the notion adopted here connotes an understanding raised by Sharif et al. (2017), who stated that it includes 4 types of taste, namely sweet, salty, sour, and bitter, impressions obtained after someone swallows a product (Winarno, 2004), transformed by taste neurons (Hiroi \& Tanimura, 2008). Following from the above understanding, the following is the results of the RSM taste response analyses. The equation necessary to find the combination of treatment for best taste is:

$$
\text { Taste }=-3.96 A+8.83 B+4 A B+1.41 A^{2}-7.34 B^{2}
$$

Where: A - Proportion of FPC (\%); B - Time (min).

The equation shows that taste response increases directly proportional to the increase in roasting time and inversely proportional to FPC proportion. The shorter roasting time and the higher the proportion of FPC, the lower the panelists' taste preference.

The validity of this result was confirmed by the data normality test as presented below. Figure 5 shows the normal plot of residual odor response, which indicates normality of data. As seen by this figure, there are strong relationship between the actual value and the predicted value. Referring to Trihaditia et al., 2018, this can be interpreted that the actual results would be close to the results predicted by the DX Program.

Using the above equation formula, FIGURE 6 shows a contour plot graph which links the value odor response and combinations of treatments (FPC proportion and roasting time). More specifically, the graph provides the following: (i) different colors which reflect different values of odor response and (ii) dotted lines which show combinations of treatments that produce the same taste response value, (iii) the effect of the combination of treatments on taste response.

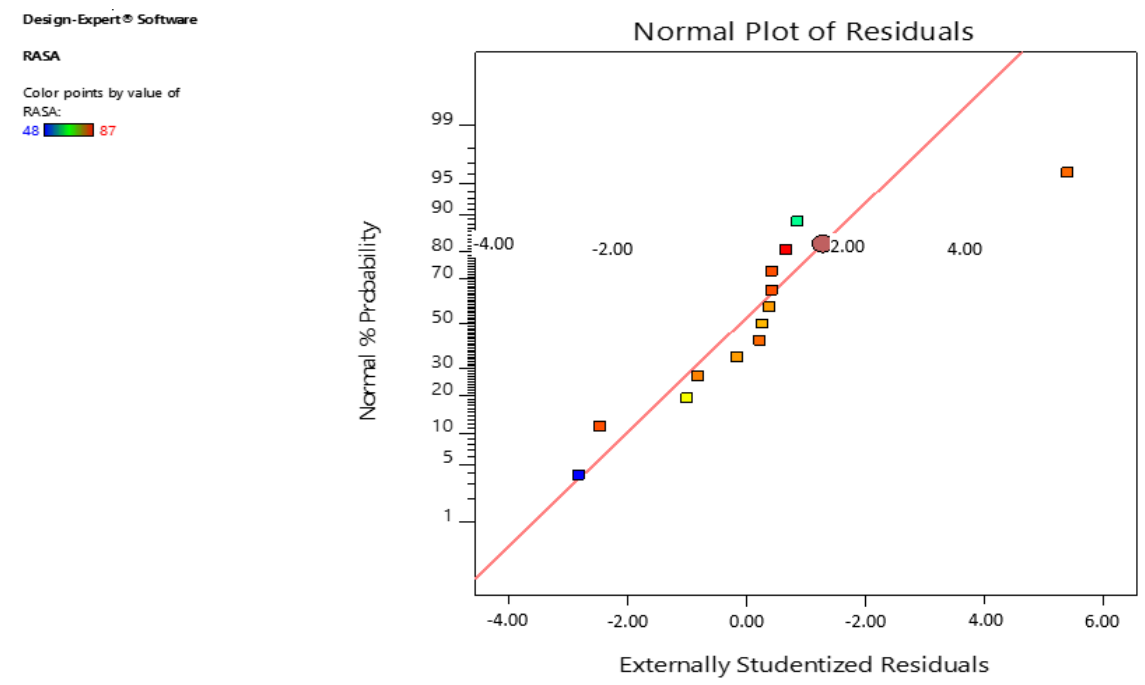

Figure 5 - Normal plot of residual taste response 
As seen in the graph, the lowest taste response value is 48 , which is indicated by the blue color; meanwhile, the highest tase response is 87 , which is indicated by the red color.

It was found that the higher the FPC and the shorter the roasting time, the smaller is the value of odor response. In the original form, the taste of gapit merely is influenced by its main normal ingredients, where the taste is sweet, owing to the presence of sugar in it (Zaitoun et al., 2019). This is what actually makes gapit is liked by children because children prefer sweetness (Mennella \& Bobowski, 2015), whose formation comes from caramelization from high temperature cooking of sugar (Kokkinidou et al., 2018). During fast roasting, as it occurred in this research, the desired high temperature did not occur so that the caramelization process was not formed perfectly. In the meantime, it caused the fish taste from the addition of a high proportion of FPC. Referring to the similar process of Windsor, 2001, the fish taste to some extent covered the weet taste of the gapit. This phenomenon can be clearly seen in the contour graph that links FPC and time treatments and the taste response.

As also seen in the graph, the boundary area for optimization has the lowest value of 60 . In this case, the predicted taste optimum value is indicated by the red point, which is 81.8. This value corresponds to a FPC proportion of $15 \%$ and roasting time of 2 (two) minutes roasting.
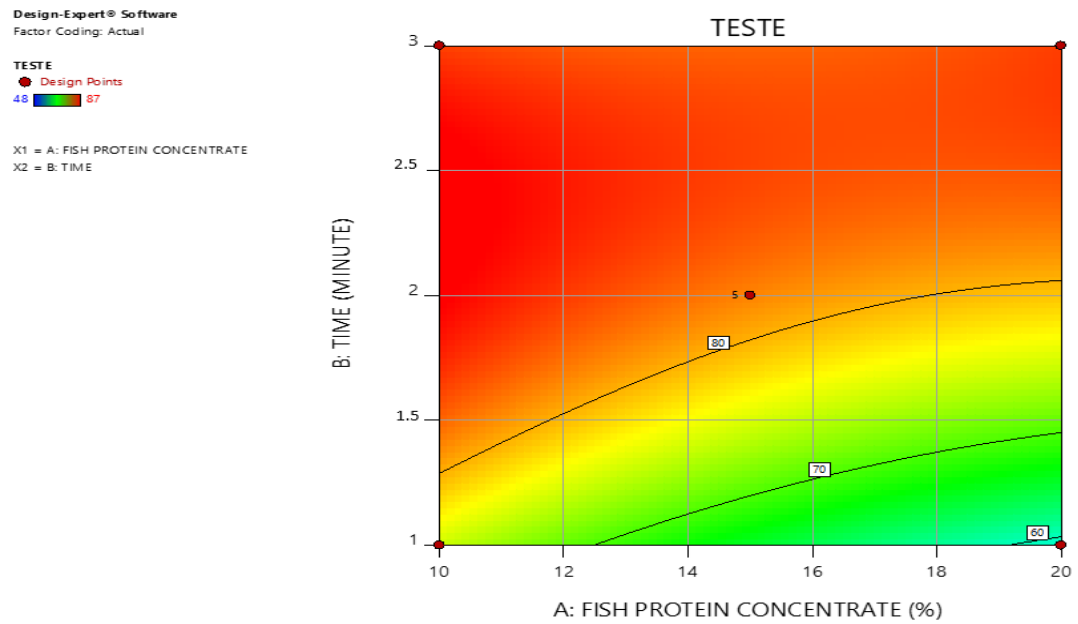

Figure 6 - Contour plot graph of taste response / optimization region of taste

Color is very important for most food products because it usually affects the first consumer's assessment of the product and also provides sensory information that can interact with taste, smell and textural cues to determine overall product acceptance (DuBose et al., 2017). Color is the light carried at the wavelength absorbed by the eye that is changed by the brain of the color we see. Light can be decomposed into a spectrum of six different colors: red, orange, yellow, green, blue and purple (Singh, 2006). In this experimental research, the results of the color-concerned RSM equation are as follows:

$$
\text { Color }=-4.19 A+3.62 B+3.75 A B+1.24 A^{2}-2.26 B^{2}
$$

Where: A - Proportion of FPC (\%); B - Time (min).

The equation shows that taste response increases directly proportional to the increase in roasting time and inversely proportional to FPC proportion. The shorter roasting time and the higher the proportion of FPC, the lower the panelists' color preference.

The validity of this result was confirmed by the data normality test as presented below. Figure 7 shows the normal plot of residual color response, which indicates normality of data. As seen by this figure, there are strong relationship between the actual value and the predicted value. Referring to Trihaditia et al. (2018), this can be interpreted that the actual results would be close to the results predicted by the DX Program. 


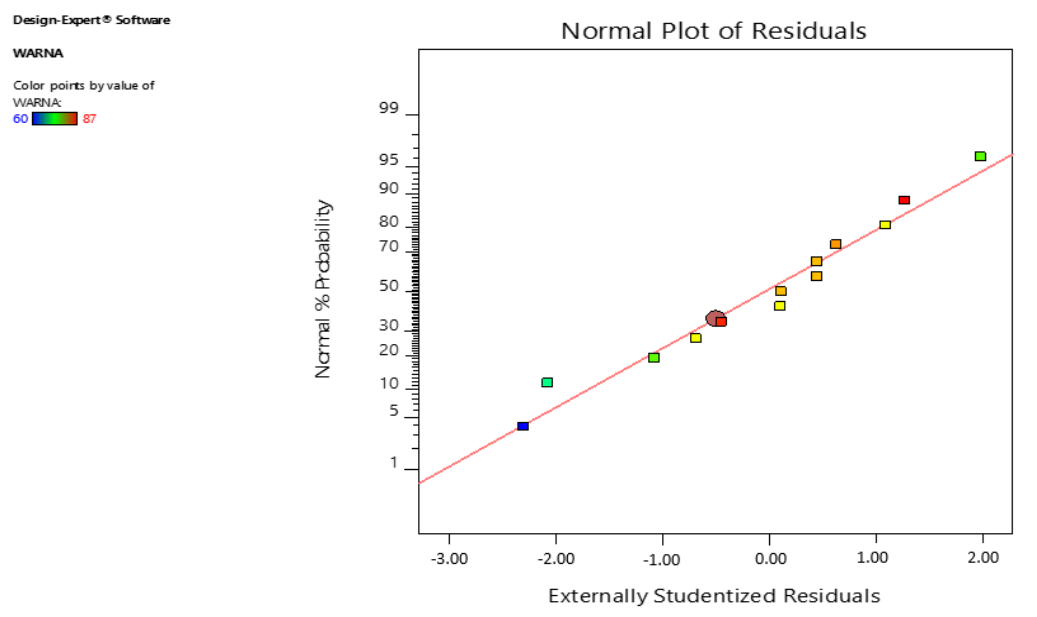

Figure 7 - Normal plot of residual color response

In this research, color was taken as a part of the focus of the analysis considering that as stated by Huang \& Lu (2015) that it is a very important attribute, which can arouse consumers' appetite and plays roles in the reception of food products. It was also considered to carry out an analysis on color because the experiment involved addition of a high content protein source (FPC) and high temperature process (roasting). Several factors have been reported to affect color changes on the product surface, amino acids, ingredients, temperature, air velocity, humidity and heat transfer into the sample. (Abraha et al., 2018); this has proven for example by Lund \& Ray (2017), who found that the amount of FPC and the lack of baking temperature will cause a brownish discoloration. In this research, the effect of treatments on color can be seen FIGURE 8 for those who wish a clearer observation. These figures show that the lowest boundary value for optimization was 70 . Meanwhile, the best optimization is shown by the red point, which is 79.4 , which corresponds to $15 \%$ FPC and 2 minute roasting time
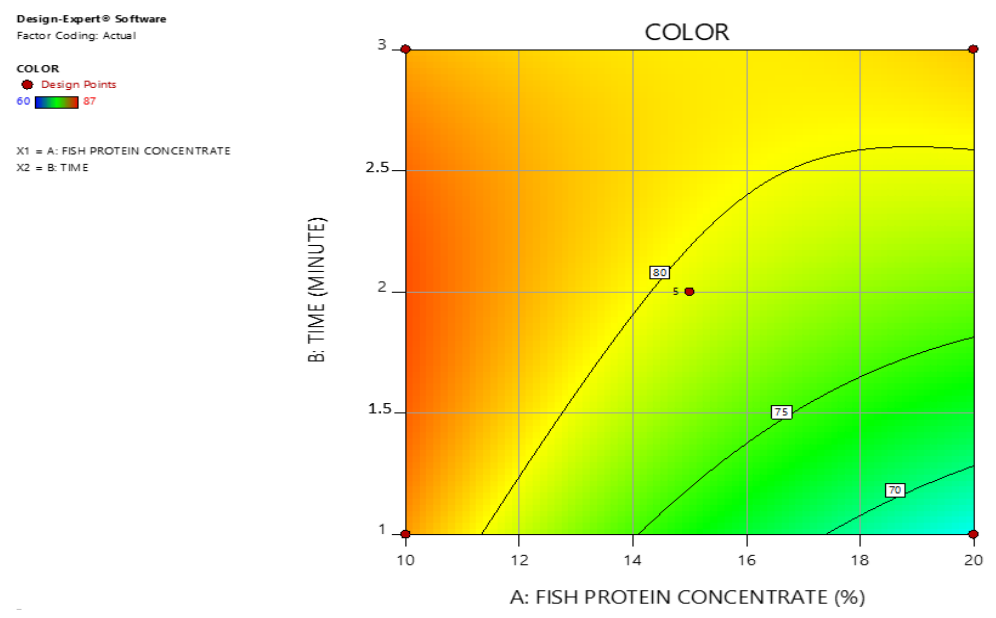

Figure 8 - Contour plot graph of color response / optimization region of color

Observation of the effect of the treatments on texture was inspired by the reports of Liu et al. (2017) and Costell \& Durán (2009). In the reports, it was stated that someone would feel a bad or good texture sensation readily when he / she chewed the food. In this research, regarding texture response, it was found that the RSM equation for optimization of treatments was as follows:

$$
\text { Texture }=-2.3 A+4.91 B+4.75 A B+0.95 A^{2}-6.8 B^{2}
$$

Where: A - Proportion of FPC (\%); B - Time (min). 
The equation shows that texture response increases directly proportional to the increase in roasting time and inversely proportional to FPC proportion. The shorter roasting time and the higher the proportion of FPC, the lower the panelists' color preference.

The validity of this result was confirmed by the data normality test as presented below. FIGURE 9 shows the normal plot of residual texture response, which indicates normality of data. As seen by this figure, there are strong relationship between the actual value and the predicted value. Referring to Trihaditia et al. (2018), this can be interpreted that the actual results would be close to the results predicted by the DX Program.
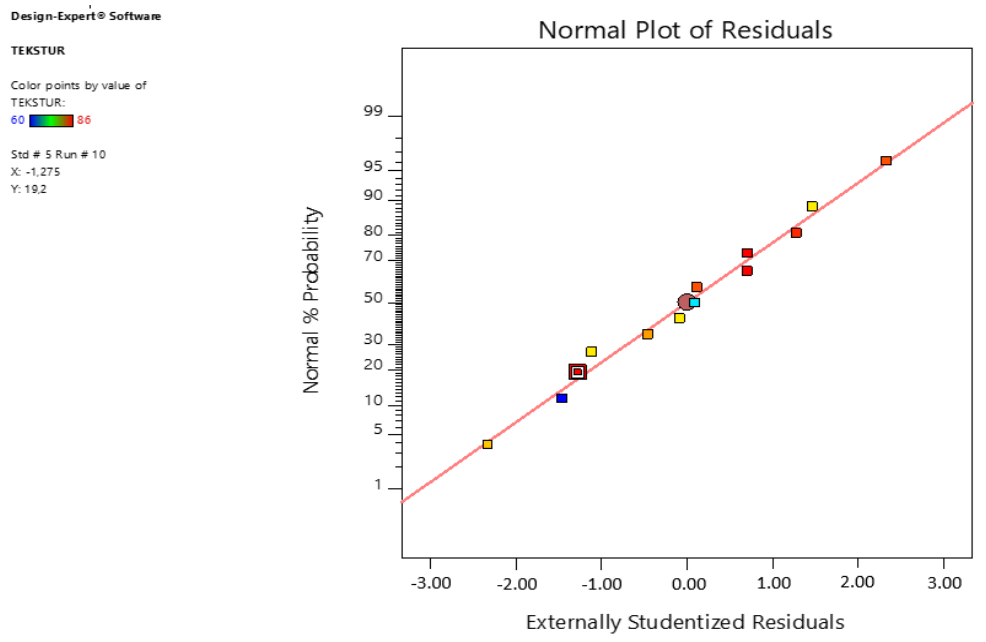

Figure 9 - Normal plot of residual texture response
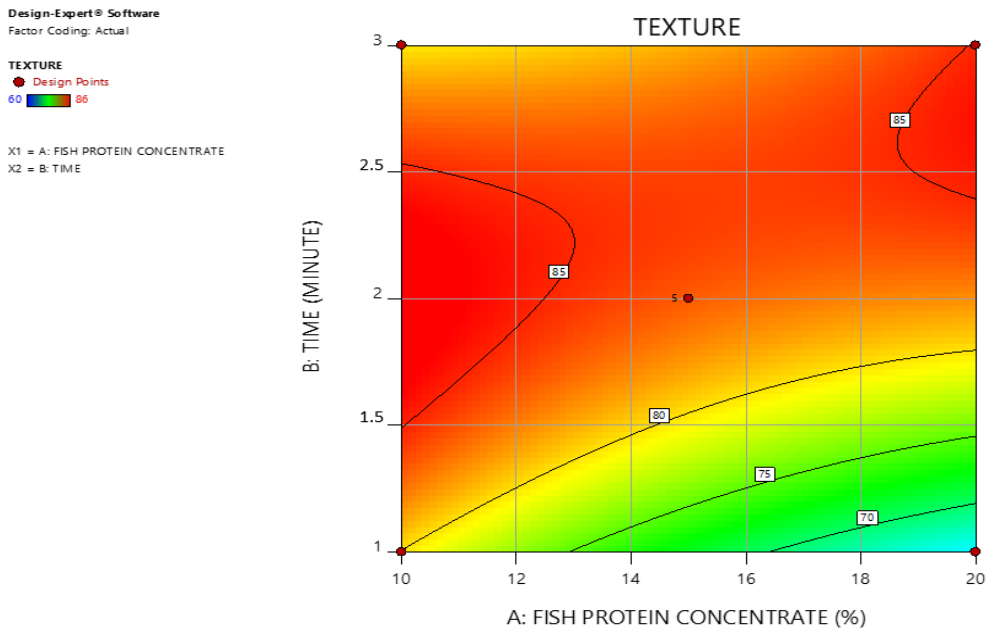

Figure 10 - Contour plot graph of texture response / optimization region of texture

The response value to the combination of treatments can be seen in the contour plot graph in Figure 10. Different colors on the contour graph also show the texture response value, blue indicates the lowest texture response value 60 and red color indicates the highest texture sensory response 86 . The dotted lines show the combination of two treatments that produce the same texture response value. Figure 12 and Figure 13 show that the lowest boundary for the optimization was 70 while the highest was 85 . The best optimization prediction of texture is shown at the red point value of 83.6 , corresponding to $15 \%$ FPC proportion and 2 minutes roasting time. This research also found that short roasting time and massive addition of FPC produced a product whose texture performance was below perfect. This might be related to finding of Jakubczyk et al. (2008), who observed a similar phenomenon, where crispness of their product was low, something that he linked with the increase in water activity. 
Following from Purnomo et al. (2012), optimization in this research was done to get sensory responses that are in accordance with the responses that could be received by the panelists (desirability). Figure 11 was presented with a purpose of optimization, where effort needed was minimum and the desired was maximum. Desirability optimization resulted in a value of 0.799 , meaning that the sensory response to the gapit accepted by panelists was $79.9 \%$. Table 6 shows the optimized treatments, targets, minimum and maximum limits, and the level of importance at the optimization stage of the formula. Based on the optimization process of the DX 11 program, a recommended combination of treatments is presented in Table 7. The treatment combination of $15 \%$ FPC and 2 minutes roasting time is the best combination with sensory response accepted by panelists by $79.9 \%$.

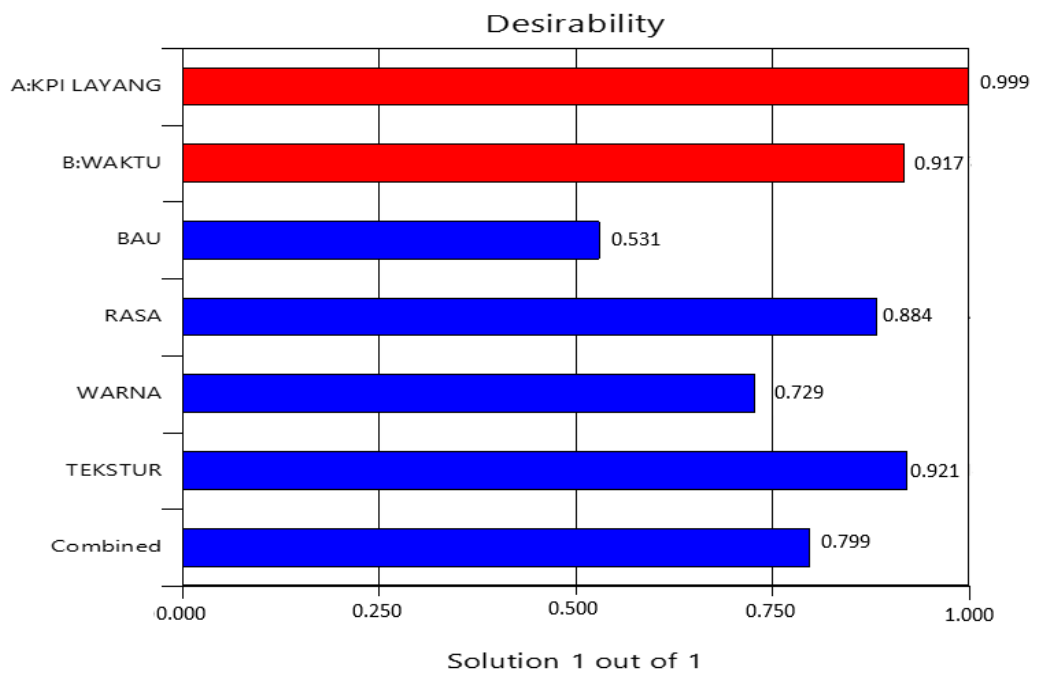

Figure 11 - Desirability

Table 6 - Components and optimized response, goal, limits, and importance in the optimization stages of the formula

\begin{tabular}{lllll}
\hline Response Component & Target & Lower Limit & Upper Limit & Importance \\
\hline Concentration FPC $(\%)$ & Range & 10 & 20 & $3(+++)$ \\
Time (Minute) & Range & 1 & 3 & $3(+++)$ \\
Smell & Maximum & 65 & 87 & $5(++++)$ \\
Taste & Maximum & 48 & 87 & $5(+++++)$ \\
Colour & Range & 60 & 87 & $3(+++)$ \\
Texture & Maximum & 60 & 86 & $5(++++)$ \\
\hline
\end{tabular}

Table 7 - Formula resulted from optimization phase

\begin{tabular}{llllllll}
\hline No & Fish protein Concentrate & Time & Smell & Taste & Color & Texture & Desirability \\
\hline 1 & 15 & 2 & 81,462 & 82,476 & 79,683 & 83,958 & 0,799 \\
\hline
\end{tabular}

The proximate figures of the treatment combination of FPC $15 \%$ and 2 minutes roasting time can be seen in Table 8 . The table the gapit proximate with the addition of FPC as compared to the commercial gapit proximate. It can be seen that the gapit produced in this research better than the commercial one and it meets the standard requirements set by the Indonesian standard (BSN, 2011).

Table 8 - The composition of the gapit proximate

\begin{tabular}{lll}
\hline Analysis & Gapit Cake with Formula & Commercial Gapit Cake \\
\hline Moisture & $4,745 \pm 0,1750$ & $6,836 \pm 0,0556$ \\
Ash & $1,1845 \pm 0,0527$ & $1,6137 \pm 0,02546$ \\
Protein & $12,35 \pm 0,1716$ & $5,88 \pm 0,558738$ \\
Fat & $3,041 \pm 0,5651$ & $5,081 \pm 0,233159$ \\
Carbohydrate & $80,643 \pm 0,1071$ & $83,551 \pm 0,263622$ \\
\hline
\end{tabular}




\section{CONCLUSION}

Interaction occurs between the components of the process of making a gapit between the proportion of FPC and the time of roasting to the sensory response of odor, smell, taste, color, and texture. Differences in the treatments to the gapit making process affect the sensory value of the odor, taste, color, and texture produced. Optimization that uses the DX 11 Program with RSM-Box-Behnken produces an optimal combination of $15 \%$ FPC and 2 minutes roasting time. In this condition, it produces a sensory value of 81.5 , taste of 82.5 , color of 79.7 , and texture of 84.0 with an acceptable response from the panelists 0 . $79.9 \%$. The final product of the gapit has a moisture content of $4.745 \% \pm 0.175$, ash of $1.1845 \% \pm$ 0.0527 , protein of $12.350 \% \pm 0.1716$, fat of $3.041 \% \pm 0.5651$, and carbohydrate of $80.664 \%$ \pm 0.107 .

\section{ACKNOWLEDGMENTS}

The authors gratefully acknowledged the financial support by The Education Center, Marine and Fisheries Research and Human Resource Agency, Ministry of Marine Affairs and Fisheries, Indonesia.

\section{REFERENCES}

1. Abraha, B., Mahmud, A., Admassu, H., Yang, F., Tsighe, N., Girmatsion, M \& Magoha, P. (2018). Production and Quality Evaluation of Biscuit Incorporated with Fish Fillet Protein Concentrate. Journal of Nutrition \& Food Sciences, 8(6), 1-13. https://doi.org/10.4172/2155-9600.1000744.

2. Ae, G., Vv, R., Ms, B., Sm, B \& Dave, D. (2013). Fish Processing Wastes as a Potential Source of Proteins, Amino Acids and Oils: A Critical Review. Journal of Microbial \& Biochemical Technology, 5(4),107-129.https://doi.org/10.4172/1948-5948.1000110.

3. Afriani, R., Kurniawati, N \& Rostini, I. (2016). Penambahan Konsentrat Protein Ikan Nila Terhadap Karakteristik Kimia and Organoleptik Biskuit. Jurnal Perikanan Kelautan, 7(1), 6-13.

4. Allen, L \& Benois, B. (2006). Guidelines on food fortification with micronutrients. Switzerland: World Health Organization Press.

5. Anugrahati, N., Santoso, J \& Pratama, I. (2012). Utilization of Catfish Protein Concentrate in Biscuit Nuri. JPHP, 15(1), 45-51.

6. Asriani. (2018). Nutritional Value of Protein Concentrate of Rejected Catfish (Clarias gariepenus) and The Application in "melarat" Crackers. Universitas Terbuka.

7. BPS. (2017). Agriculture Producer Price Statistics of Food Crops, Animal Husbandry and Fishery Subsector (S. S. H. Perdesaan, Ed.). Jakarta: Badan Pusat Stat.

8. BPS. (2018). Produksi Perikanan Laut Yang Dijual Di Tempat Pelelangan Ikan Provinsi Jawa Tengah 2017 ini. Provinsi Jawa Tengah: Badan Pusat Statistik Provinsi Jawa Tengah.

9. BRHO. (2018). Rekapitulasi status Gizi Hasil Penimbangan serentak Bulan Agustud 2018. Blora Regency Health Office.

10. BSN. (1992). Cara Uji Makanan and Minuman SNI 01-2891-1992. Jakarta: Badan Standarisasi Nasional.

11. BSN. (2006). Petunjuk pengujian organoleptik and atau sensori SNI No. 01-2346-2006. Jakarta, Indonesia: Badan Standarisasi Nasional.

12. BSN. (2011). Standar Nasional Indonesia Biskuit No. 2973:2011. Retrieved from www.bsn.go.id.

13. Costell, E \& Durán, L. (2009). Food Texture: Sensory Evaluation. Food Engineering, II, 238-244.

14. Defira, R., Desmelati \& Dahlia. (2019). The Effect of Nile Tilapia (Oreochromis Niloticus) Protein Concentrate Fortification on Sweet Bread. Jurnal Agroindustri Halal, 5(2), 122131. 
15. Dewita., Syahrul \& Isnaini. (2011). Utilization of Patin Fish Protein Concentrate To Make Biscuit and Snack. JPHPI, 14(1), 30-34.

16. DuBose, C..., Cardello, A \& Maller, O. (2017). Effects of Colorants and Flavorants on Identification, Perceived Flavor Intensity, and Hedonic Quality of Fruit - Flavored Beverages and Cake. Journal Food Science, 45(5), 1393-1399 \& 1415. https://doi.org/10.1111/j.1365-2621.1980.tb06562.x.

17. Grover, Z \& Ee, L.. (2009). Protein Energy Malnutrition. Pediatric Clinics of NA, 56(5), 1055-1068. https://doi.org/10.1016/j.pcl.2009.07.001.

18. Hapsoro, K. (2013). The Production Practice of Yellow Gourd Semprong. Surakarta Sebelas Maret University, Surakarta.

19. Hasan, L., Yusuf, N \& Mile, L. (2014). Pengaruh Penambahan Kappaphycus alvarezii terhadap Karakteristik Organoleptik and Kimiawi Kue Tradisional Semprong. 2(September).

20. Hiroi, M \& Tanimura, T. (2008). Hedonic Taste in Drosophila Revealed by Olfactory Receptors Expressed in Taste Neurons. PLoS ONE, 3(7), 1-9. https://doi.org/10.1371/journal.pone.0002610.

21. Huang, L \& Lu, J. (2015). Eat With Your Eyes: Package Color Influences The Expectation Of Food Taste And Healthiness Moderated By External Eating. Marketing Management Journal, 25(2), 71-87.

22. Irmayanti, W., Hermanto \& Asyik, N. (2017). Organoleptic and Proximate Analysis of Biscuit Based-Sweet Potato and Mung Bean Flour. J. Sains and Teknologi Pangan, 2(2), 413-424.

23. Jakubczyk, E., Marzec, A \& Lewicki, P.. (2008). Relationship Between Water Activity Of Crisp Bread And Its Mechanical Properties And Structure. 58(1), 45-51.

24. Kemenkes. (2013). Riset Kesehatan Dasar. Jakarta: Kementerian Kesehatan RI.

25. Keshani, S., Chuah, L., Nourouzi, M., Russly, A \& Jamilah, B. (2010). Optimization of concentration process on pomelo fruit juice using response surface methodology (RSM). International Food Research Journal, 17, 733-742.

26. Khikmawati, N. (2014). Quality of Gapit Cake with Purple Sweet Potato Composite. Food Science and Culinary Education Journal, 3(1), 56-61. Retrieved from http://journal.unnes.ac.id/sju/index.php/fsce.

27. Kholilah, W. (2002). Daya Terima and Nilai Gizi Biskuit dengan Penambahan Kosentrat Protein Ikan Layang (Decapterus russelli Ruppel) and Difortifikasi Zat Besi. Institut Pertanian Bogor.

28. Kokkinidou, S., Peterson, D., Bloch, T \& Bronston, A. (2018). The Important Role of Carbohydrates in the Flavor, Function, and Formulation of Oral Nutritional Supplements Smaro. Jurnal Nutrients, 10(742), 1-10. https://doi.org/10.3390/nu10060742.

29. Liu, D., Deng, Y., Sha, L., Hashem, A \& Gai, S. (2017). Impact of oral processing on texture attributes and taste perception. Journal of Food Science and Technology, 54(8), 2585-2593. https://doi.org/10.1007/s13197-017-2661-1.

30. Lund, M. \& Ray, C.. (2017). Control of Maillard Reactions in Foods: Strategies and Chemical Mechanisms. J. Agric. Food Chem., 65, 4537-4552. https://doi.org/10.1021/acs.jafc.7b00882.

31. Maggini, S., Pierre, A \& Calder, P. C. (2018). Immune Function and Micronutrient Requirements Change over the Life Course. (Figure 1). https://doi.org/10.3390/nu10101531.

32. Mennella, J. \& Bobowski, N. (2015). Children Taste Learning Genetic variation Diet The sweetness and bitterness of childhood: Insights from basic research on taste preferences. Physiology \& Behavior, 152, 502-504.

33. Mohamed, G. F., Sulieman, A. M., Soliman, N. G \& Bassiuny, S. S. (2014). Fortification of Biscuits with Fish Protein Concentrate. World Journal of Dairy \& Food Sciences, 9(2), 242-249. https://doi.org/10.5829/idosi.wjdfs.2014.9.2.1142.

34. Montgomery, D. C. (2013). Design and Analysis of Experiments Eighth Edition (8th ed.). USA: John Wiley \& Sons, Inc.

35. Nielsen, S. (2010). Food Analysis (4th ed.). USA: Springer. 
36. Ningsih, R. (2018). Strengthening Indonesia's Exports of Fish and Processed Fish Products to Canada. Jakarta.

37. Nitisari, I. (2016). The Concept of Good Food Production Methods (Cppb) On Making Egg Roll in Smes "Q Is" Ds. Tambakboyo, Kec. Mantingan, Kab. Ngawi, East Java. Universitas Sebelas Maret.

38. Nova, C \& Kristiastuti, D. (2017). Pengaruh Substitusi Mocaf (Modified Cassava Flour) and Penamahan Jus Daun Bayam (Amaranthus Spp) Terhadap Sifat Organoleptik Kue Gapit. E-Journal Boga, 5(1), 1-10.

39. Nugroho, B., Boesono, H \& Bambang, A. (2013). Price Fluctuation And Distribution Flow Of Fish (Decapterus Spp) From The Results Of Mini Purse Seine Capacity Landed In Pekalongan Archipelago Port. Journal of Fisheries Resources Utilization Management and Technology, 2(1), 23-32.

40. Nurmiah, S., Syarief, R., Sukarno, Peranginangin, R \& Nurtama, B. (2013). JPB Kelautan and Perikanan. JPB Kelautan and Perikanan, 8(1), 9-22.

41. Oramahi, H. (2016). Optimasi dengan RSM and Rancangan Percobaan. Yogyakarta: Gava Media.

42. Patimah, S., Arundhana, I., Mursaha, A \& Syam, A. (2019). Current Research in Nutrition and Food Science Development of Foxtail Millet and Flying Fish Flour-Based Cookies as Functional Food. Current Research in Nutrition and Food Science Journal, 07(2).

43. Purnomo, E., Sitanggang, A., Agustin, D \& Hariyadi, P. (2012). Formulation And Process Optimization Of Muffin Produced From Composite Flour Of Corn, Wheat And Sweet Potato Formulation And Process Optimization Of Muffin Produced From Composite Flour Of Corn, Wheat And Sweet Potato. J. Teknol and Industri Pangan, 23(2), 165-172. https://doi.org/10.6066/jtip.2012.23.2.165.

44. Rushing, H., Karl, A \& Wisnowski, J. (2013). Design and Analysis of Experiments by Douglas Montgomery: A Supplement for Using JMP(R). Cary, North Carolina, USA.: SAS Institute Inc.

45. Sharif, M., Sharif, H \& Nasir, M. (2017). Sensory Evaluation and Consumer Acceptability. In Tahir Zahoor and Masood Sadiq Butt (Ed.), Sensory Evaluation and Consumer Acceptability Mian. Faisalabad: University of Agriculture, Faisalabad, Pakistan.

46. Singh, S. (2006). Impact of color on marketing. Emerald Insight, 44(6), 783-789.

47. Stat-Ease. (2018). Handbook for Experimenters. Minneapolis: Stat-Ease.

48. Sukasih, E, Setyadjit, Sunarmani \& Pertiwi. (2018). Optimisation of the Instant Cavendish Banana Flour Formula by Response Surface Method. Jurnal Penelitian Pascapanen Pertanian, 15(1), 1-11.

49. Sulistiyowati, S. (2010). Manajemen Pendidikan Anak Usia Dini pada Raudhatul Athfal Cemani Grogol Sukoharjo. Sekolah Tinggi Agama Islam Negeri Surakarta.

50. Trihaditia, R., Syamsiah, M \& Awaliyah, A. (2018). Penentuan Formulasi Optimum Pembuatan Cookies Dari Bekatul Padi Pandanwangi Dengan Penambahan Tepung Terigu Menggunakan Metode Rsm (Response Surface Method). Agroscience, 8(2), 212230.

51. UNHCR. (2001). Child and Adolescent Development (4th ed). Switzerland: United Nations High Commissioner for Refugees.

52. USAID. (2018). An Overview of Marine Resource Management for Small-Scale Fisheries and Critical Marine Habitats in Indonesia. In The State of the Sea: Indonesia (1st ed.). Jaka: USAID SEA Project on behalf of USAID Indonesia.

53. Widyaningsih, T., Lawalata, J \& PS, P. (1986). Kosentrat Protein Ikan; Bahan Pangan dengan Kadar Protein Tinggi. In Jurnal Agritech (Vol. 6). Yogyakarta.

54. Winarno, F. G. (2004). Kimia Pangan and Gizi. Jakarta: PT Gamedia Pustaka Utama.

55. Windsor, M. (2001). Fish Protein Concentrate. In International Fisheries and Aquatic Research, SIFAR. Italia.

56. Zaitoun, M., Ghanem, M \& Harphoush, S. (2019). Sugars: Types and Their Functional Properties in Food and Human Health Sugars: Types and Their Functional Properties in Food and Human Health. International Journal of Public Health Research, 6(4), 93. 